\title{
Crested Barbary dove (streptopelia risoria) in pet shop of kushtia, Bangladesh
}

\section{Short communication}

Crested fancy pigeons or pigeons are very common in Bangladesh but this is rare in doves. A shop in Kushtia district of Bangladesh, they collected one wild type but crested Barbary Dove from Khulna and another white crested form from an unknown locality. Crowned pigeons are not available in Bangladesh. Only in Chittagong, Comilla, and Dhaka there some birds were found. From the personal communication with the rearers, they said that productivity of those crested pigeons is very slow. In nature, Topknot and Pheasant Pigeons have tuft and occipital crest. History says, selective breeding of fancy pigeons in Egypt they produced lots of crested pigeon varieties but this was not common in dove. Crested Choiseul Pigeon was extinct and now only Australian Crested Dove have upright crest. Selective breeding may produce huge crests in dove. Pigeons have various pattern of feather which created abnormal size or position of the feathers. ${ }^{1}$ Huge feathers of head cover the head and eyes and feather in legs and feet is muff. Most of the time abnormal feathers can cause difficulties in feeding, perching, flying, and breeding. Some breeds are unable to mate without trimming of those abnormal feathers. Several genes are involved in the various feather abnormalities have not been investigated. $^{2}$

Scientists have decoded the genetic map of the rock pigeons head crests. There are about 350 breeds of rock pigeons in the world with different sizes, shapes, colors, beaks, vocalizations, and arrangements of feathers. Depending on shape the head crests are called hood, shell, peak, and rose. Moreover, more than 80 of the 350 pigeons have head crests which play an attracting role for mating behavior. The biologists discovered 1.1 billion base pair and 17,300 genes in Rock Pigeon. In 1941, Levi ${ }^{3}$ in his book 'The Pigeon' mentioned various head and legfeathers of fancy pigeons. Western Crowned Pigeon (Goura cristata) has imported in Chittagong, Bangladesh in 2003. In Bangladesh though this is few but for higher price squabs are sold by huge amount of money. Both sexes are almost similar but males are often larger than females. ${ }^{4}$ It is one of the largest and is considered one of the most beautiful members of the crested pigeon family. Due to habitat loss, limited range, and overhunting this is now vulnerable according IUCN red list of threatened species. ${ }^{5}$ In Bangladesh 29 fancy pigeons have crest $^{6}$ and recently found crest in Barbary Dove in captivity. Due to artificial selection in pigeons this incidents are very common but in dove for late domestication this is not common. But in future for the development of cage birds breeding it will happen enormously.

Choiseul crested pigeon: This nice crested pigeon has been extinct from early $20^{\text {th }}$ century. It can be an evolutionary evidence of the head feathers of doves or pigeons. Extant three species of crowned pigeons (Goura spp) very similar with this Choiseul Pigeon (Plate 1).

Crowned pigeons: This is large, blue-grey pigeon with blue crest and dark blue mask feathers around its eyes. After hatching, its squab shows nice crest within 7-14 days. This is elegant blue lace-like crests and red iris. The bird may be easily recognized by the unique white tips on its crests and larger than the other crowned pigeons. One of three superficially similar species of crowned pigeons (Victorian-
Volume 8 Issue 4 - 2019

\author{
Ashraful Kabir M \\ Department of Biology, Saidpur Cantonment Public College, \\ Bangladesh
}

Correspondence: M Ashraful Kabir, Department of Biology, Saidpur Cantonment Public College, Bangladesh, Email ashraful_wb@yahoo.com

Received: March 07, 2019 | Published: August 30, 2019

Goura victoria, Western- Goura cristata and Southern- Goura scheepmakeri) are still surviving in the world (Plates 2-4).

Topknot Pigeon (Lopholaimus antarcticus): This is a native pigeon in Australia and have occipital and frontal crest. The crest consists of grey feathers at the front and brown-red feathers at the back. They are completely arboreal. Topknot Pigeons are a protected species in Australia and also called Flock Pigeon (Plate 5).

Australian Crested Pigeon (Ocyphaps lophotes): It lives in flocks with about 100 individuals. This pigeon is very important bird for spreading seeds. Sexes are similar (Plate 6).

Pheasant Pigeon (Otidiphaps nobilis): The Pheasant Pigeon is an unusual pigeon of uncertain affinities within the family Columbidae, and is monotypic within the genus Otidiphaps, and the sub-family is Otidiphabinae. Pheasant Pigeon has filled the ecological niche of a Partridge (while Goura Crowned Pigeons have a similar lifestyle to larger Pheasants, Grouses or Turkeys) (Plate 7).

Barbary Dove (Streptopelia risoria): This is wild but in Bangladesh considered a nice cage bird. In intensive system, it produces quantity of squab. It has wild type head but suddenly I found in Kushtia, Bangladesh two specimens both were crested (wild type and white color with crest, Plates 8-9). (Plates 1-7) were collected from internet for comparing the crest of pigeons and doves with the findings.

Frontal crests are found in several domestic fancy pigeons including Trumpeter and Double-crested Priest. Some extant pigeon breeds have occipital and nape-crest like American Crest, Russian Highflyer, and Archangel. Breeding studies indicate that the occipital crest is a recessive in domestic pigeons. ${ }^{7}$ Some Trumpeter has both occipital and frontal crest. ${ }^{1}$ Topknot Pigeon (Lopholaimus antracticus) possesses both a frontal and occipital crest reminiscent of domestic trumpeters. ${ }^{8}$ A conspicuous occipital crest is to be found in the nominate form of the Pheasant Pigeons (Otidiphaps nobilis). ${ }^{9}$ Columbiformes order is very successful rank among the avian taxa. ${ }^{10}$ The crest of doves or pigeons can be a tool for the study of Genetics. Due to produce new variety this is good. All foreign doves in Bangladesh are now beautiful cage bird with the Munia, Finch, Cockatoo, Parrot, and Parakeet. ${ }^{11}$ In 
the field of cage bird rearing, there is no shortcut for producing crested dove without the knowledge of selective breeding.

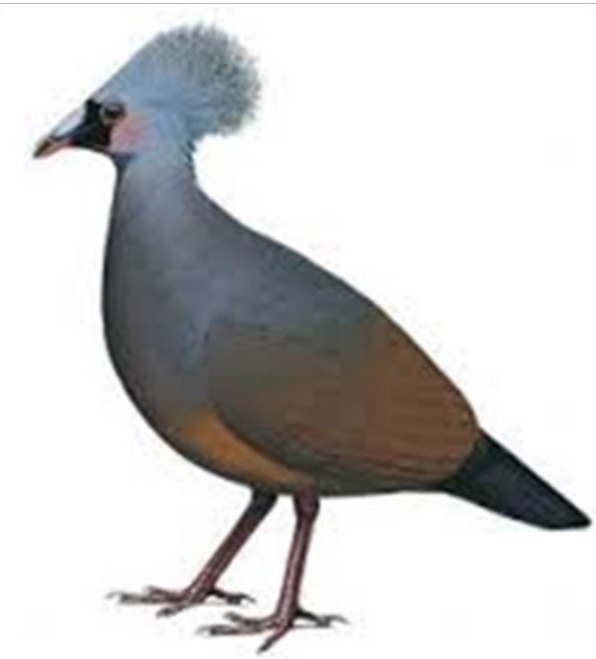

Plate I Choiseul (extinct).

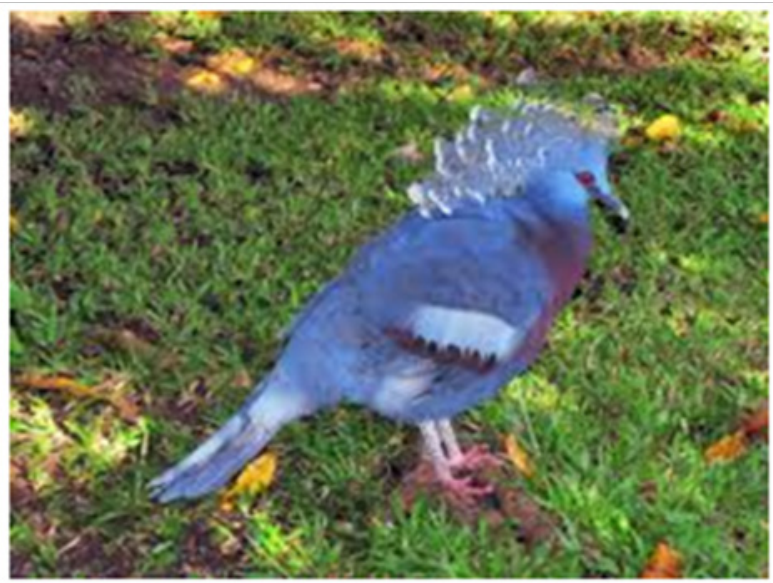

Plate 2 Victorian.

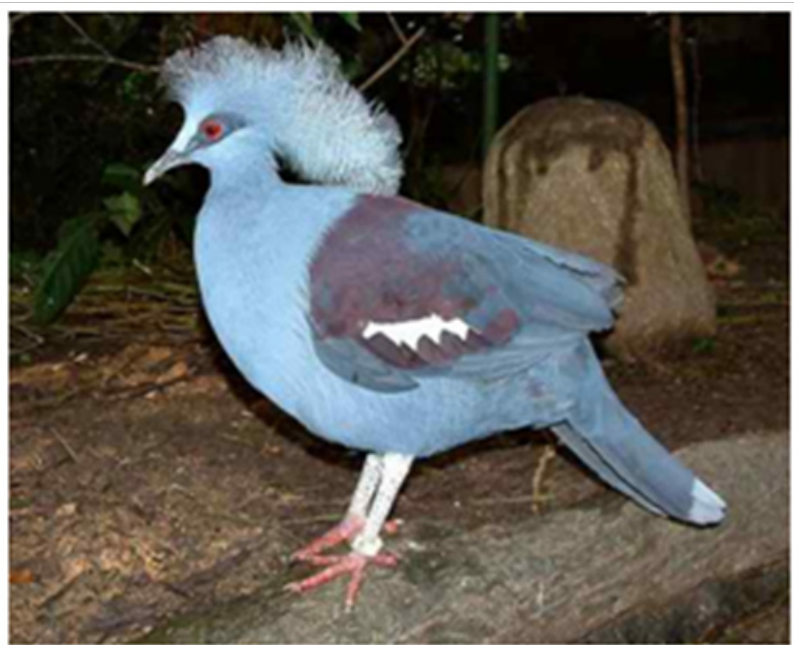

Plate 3 Western.

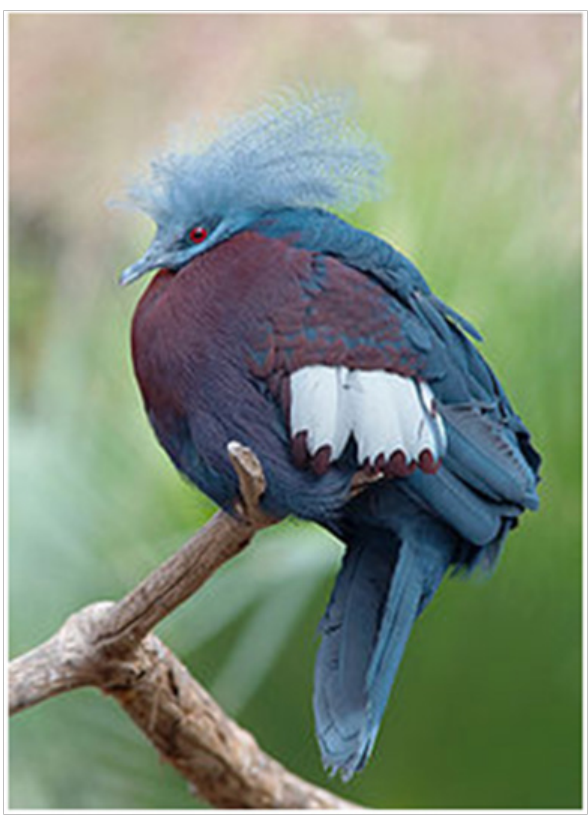

Plate 4 Southern.

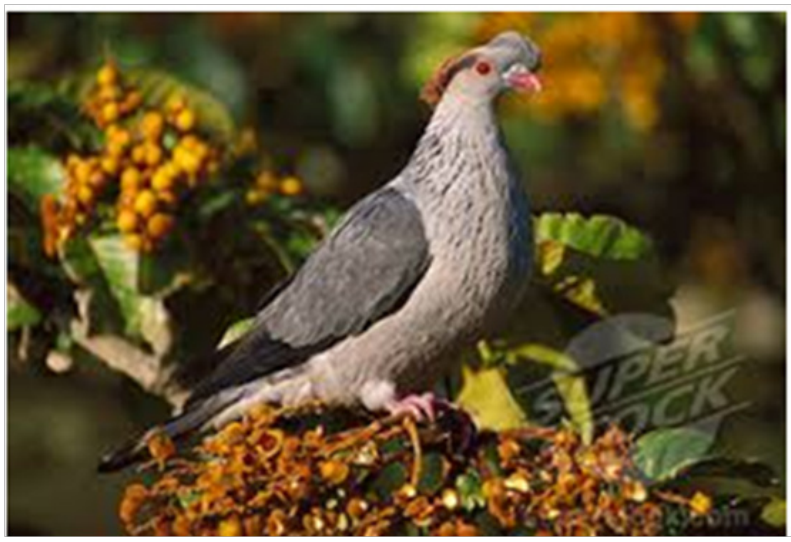

Plate 5 Topknot.

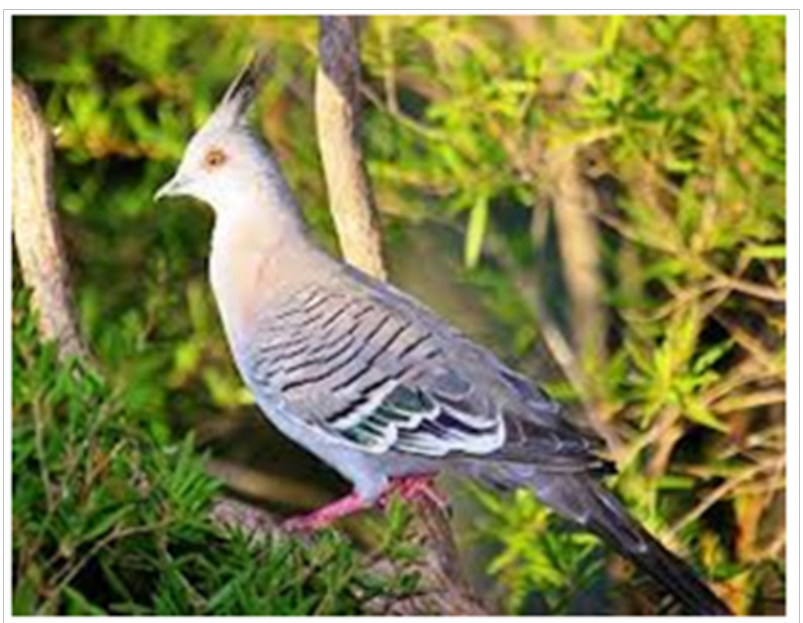

Plate 6 Australian crested. 


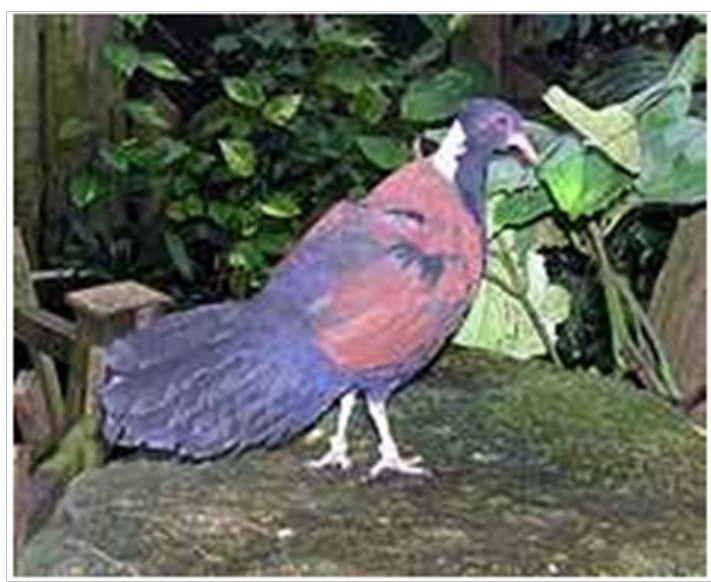

\section{Acknowledgments}

None.

\section{Conflicts of interest}

The author declares that there are no conflicts of interest.

\section{References}

1. Baptista LF. Martinez Gomez JE, Horblit HM. Darwin's pigeons and the evolution of the Columbiformes: recapitulation of ancient genes. Acta Zoológica Mexicana. 2009;25:719-741.

2. Wexelsen H. Types of leg feathering in pigeons. Hereditas. 1933;18:192198.

3. Levi WM. The Pigeon. Levi Publishing Co., Inc., Sumter, SC. 1941;640 p.

4. Gibbs D, Barnes E, Cox J. Pigeons and doves: a guide to the pigeons and doves of the world. Pica Press, London. 2001;615 p.

5. BirdLife International. Goura cristata. IUCN Red List of Threatened Species. Version 2013.2. International Union for Conservation of Nature. 2013.

6. Kabir MA. Head-Leg feathers in fancy pigeons of Bangladesh. American Res J of Bio Sciences. 2015;1(1):48-51.

7. Johansson I. Studies on inheritance in pigeons via Number of tail feathers and uropygial gland. Genetics. 1927;12(3):93-107.

8. Frith HJ. Pigeons and doves of Australia. Rigby Publishers, Sydney, Adelaide, Australia. 1982.

9. Delacour J. Wild pigeons and doves. TFH Publications, Inc., Neptune, NJ. 1980.

10. Baptista LF, Trail PW. The role of song in the evolution of passerine diversity. Systematic Biology. 1992;41(2):242-247.

Plate 8 Barbary dove (wild type)

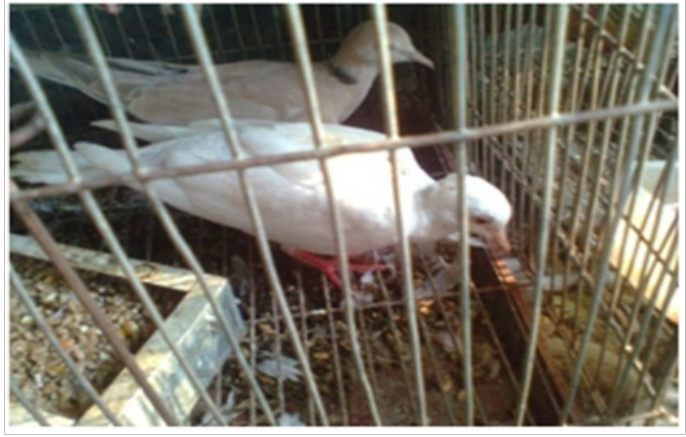

11. Kabir MA. Available exotic cage birds in Bangladesh. Glob J Mul App Sci. 2014;2(1):1-4.

Plate 9 Barbary dove (white). 